\title{
Dealing with grief related to loss by death and chronic pain: Suggestions for practice. Part 2
}

This article was published in the following Dove Press journal:

Patient Preference and Adherence

26 June 2010

Number of times this article has been viewed

\author{
Elin Dysvik' \\ Bodil Furnes ${ }^{2}$ \\ 'Department of Health Studies, \\ Faculty of Social Sciences, \\ ${ }^{2}$ Department of Mathematics and \\ Natural Science, University of \\ Stavanger, Stavanger, Norway
}

Correspondence: Elin Dysvik

University of Stavanger, Faculty of Social Sciences, Department of Health Studies, $\mathrm{N}-4036$, Stavanger, Norway

Tel +47 5I 834 I000

Fax +47 5I 83I 550

Email elin.dysvik@uis.no
Objective: This paper, the second of two, represents a theoretical framework for interventions related to loss by death of someone close, or chronic pain. This work is based on our previous understanding where grief is considered an integrated experience which involves movements on several continua.

Methods: We have performed a comparison between two interventions dealing with grief and chronic pain using different designs. Interrelated experiences and processes were identified.

Results: Life phenomena like grief and loss caused by death and chronic pain, seem to have many qualities in common and may overlap each other. A common core containing emptiness, vulnerability and exhaustion is identified.

Discussion: Despite advances in research and thinking in recent years, several issues related to grief caused by death or chronic pain remain a challenge in clinical settings and research. When preparing interventions, we must pay attention to the relearning process, the common core and the interplay between these bodily expressions.

Conclusion: We believe there is a value in future research and practice to consider losses caused by death and chronic pain, together as well as separately. Our comprehensive approach indicates that understanding the processes involved in one sort of grief may help understand the processes involved in the other.

Keywords: nursing, program development, grief

\section{Introduction}

This is a follow-up study based on our previous article, ${ }^{1}$ which constitutes a theoretical framework for understanding grief related to loss caused by death of someone close, and loss caused by chronic pain, as unique experiences. Common for these phenomena is that grief influences the existential parts of life and is described as a reconstructive process following such suffering. ${ }^{2}$ The examination of grief caused by death and chronic pain reveals many similarities. In this context, the subjective meaning the patient expresses related to his or her loss, will represent a starting point in grief work. This understanding indicates the fact that support to people who suffer grief caused by death or chronic pain, should focus on grief as a specific type of experience taking a phenomenological perspective. ${ }^{1}$ Here a movement from relearning the world and adaptation becomes essential in grief work independent of its cause. ${ }^{1}$ Previous intervention studies performed by the present authors related to loss and grief caused by death and chronic pain, ${ }^{3-5}$ have several common features including a structured group approach, homework and writing as an important tool following several distinct steps. The main focus is on thoughts and emotions to induce behavioral changes. In one 
study, ${ }^{3,4}$ writing was introduced as homework and provided the platform for the following group meetings. In the other study, ${ }^{5}$ writing was conducted in grief writing groups and using diaries.

Loss caused by death is naturally connected to grief. However, loss caused by chronic pain may also lead to grief experiences. These losses have the potential to elicit existential difficulties such as lack of control and reduced predictability about life. Such changes may diminish the person's well-being, hope for the future and ability to cope. ${ }^{6}$ Loss as a life experience may concern something irrevocable and the feelings connected to what is lost. As such, grief may be related to several losses caused by chronic pain, like loss of health, loss of work or social relations. ${ }^{7}$ This is also consistent with Parkes ${ }^{8}$ who discovered parallel processes of grieving whether the loss was caused by losing a limb or through the death of someone close. Such losses are naturally integrated in the human experience, but sometimes they unfold in ways which are difficult to define. Dealing with loss and grief refers to an individual experience and some central aspects of grief processing and grief work incorporate issues such as expressing grief, gaining an awareness of the loss, retaining and sustaining some ties to what is lost, acknowledgement through new insights and an adjustment to the new life situation. ${ }^{5}$ Walker et $\mathrm{al}^{9}$ suggest that material losses as well as perceptions of loss are prominent issues for those seeking help from pain clinics for their pain problems. Whitley-Reed ${ }^{10}$ reports that grief therapy is effective in reducing pain and depression in a group of chronic pain sufferers. Those who suffer grief related to loss by death may also benefit from group approaches where cognitive, emotional and behavioral components are highlighted. ${ }^{5}$ Independent of the cause, the grief experience may involve the whole life situation and represents a huge challenge for the sufferers as well as the health care workers.

\section{Aim}

Based on the authors' previous studies ${ }^{1,3-5}$ we now want to extend the discussion in order to deepen our understanding of the relationship between chronic pain, loss and grief. Furthermore, we will highlight important elements when developing integrated programs in chronic pain- and grief management.

\section{Theoretical framework}

Our previous integrated programs dealing with grief related to loss by death and nonmalignant chronic pain ${ }^{1}$ contributes to an extended understanding of these phenomena. In addition, two previous programs for interventions ${ }^{3-5}$ based on a group approach, will now be introduced as a basis for our integrated program. The summaries of the organization and the main differences in our programs are presented (Table 1), and each program will also be described in more detail as a foundation for discussion (Appendix A).

\section{Group approach}

Group approaches are used in our previous studies ${ }^{3-5}$ and have many advantages in the treatment of grief and loss caused by death or chronic pain. Firstly, acccording to Keefe et al ${ }^{11}$ a group provides a setting in which patients can be in touch with others who have similar problems. Secondly, group participation can help patients gain a better understanding of pain and grief and the role of their own behavior, thoughts and feelings regarding the perception of their situation. Thirdly, patients can be taught effective coping skills and how these skills can be integrated in daily life. ${ }^{11}$ Yalom ${ }^{12}$ emphasizes several important supportive factors such as hope, acceptance, universality and altruism that can be successful when conducting groups. In addition, self-revelation factors encompass self-disclosure and the expression of emotions, while psychological work factors include self-understanding and interpersonal learning. Lastly, the learning from others

Table I Organization of the grief and pain management program

\begin{tabular}{|c|c|c|c|c|}
\hline Study & Course & $\mathbf{N}$ & Length & Components in each meeting \\
\hline Quantitative including a & Chronic pain & 87 & 8 weeks at 3 hours, & Cognitive behavioral approach in groups \\
\hline \multirow[t]{3}{*}{ qualitative component ${ }^{3}$} & & & Follow up after 6 and 12 months & Supervised dialogue \\
\hline & & & & Physical activity \\
\hline & & & & Education and corresponding homework \\
\hline Quantitative including a & & 113 & 8 weeks at 5 hours, & \\
\hline qualitative component ${ }^{4}$ & & & Follow up after 6 and 12 months & \\
\hline \multirow[t]{6}{*}{ Qualitative $^{5}$} & Grief & 13 & 10 meetings during 5 months & Writing in a group \\
\hline & & & (in total): & Supervised dialogue \\
\hline & & & - Every second week & Writing in a diary at home \\
\hline & & & at 2.5 hours for 3 months & between each meeting \\
\hline & & & - after these once a & Homework \\
\hline & & & months at 2.5 hours & Supervised dialogue \\
\hline
\end{tabular}


factors, like modeling seem to be important and incorporate vicarious learning, guidance and education. ${ }^{12}$ In all such group approaches, Linton ${ }^{13}$ notes that the content of the group approach and how the therapy is practiced are good predictors of success or failure.

\section{Cognitive behavioral theory (CBT)}

The pain management programme ${ }^{3,4}$ is based on a cognitive behavioral approach. In recent decades, the multiple disturbing effects of chronic pain on patients' physical and psychosocial functioning have been widely recognized in rehabilitation. Biomedical treatment only partly alleviates these consequences of chronic pain. ${ }^{14}$ As a result, there has been considerable interest in psychological treatment models, which address the complex interaction of biological symptoms and psychosocial factors. ${ }^{14}$ Major aims of CBT, within the broad framework of learning theory, are to improve quality of life, coping skills and physical functioning. CBT for chronic pain involves a variety of interventions that share three basic components: emphasizing the patients' ability to help themselves rather than depending on therapists; Interest in the nature and modification of patients' thoughts, feelings and behavior; Behavior therapy procedures promoting change (such as homework, relaxation, social skill training, and physical activity). ${ }^{15}$

\section{Writing theory}

A major component of the grief management program is process oriented writing theory. Here it is fundamental that there is a dynamic relationship between thought and language, and thus an active use of language stimulates and promotes thought activity. ${ }^{5,16-20}$ Writing is a creative developmental process. In this process thoughts emerges and the writer may experience increased awareness and knowledge. ${ }^{16,18-20}$ Writing one's own ideas opens a channel to get acquainted with one's own thinking potential. ${ }^{21}$ Studies indicate that to write and form a story, is to reflect on events and contributes to self understanding and new insight. ${ }^{5,23,24}$ Creative writing in the grief work becomes a tool for acknowledgement and knowledge. The writing process helps the writer to identify new relationships as well as to reveal any lack of coherence and understanding. ${ }^{5,18,19}$ Elements from process oriented writing theory is central to the construction in writing program where grief work consists of handling thoughts and feelings.

\section{Chronic pain management program}

The intervention was active, time limited and structured. The multidisciplinary team consisted of a physician, a physiotherapist, a psychologist and two nurses. The groups were conducted according to a structured protocol, and two supervisors were involved in each group. Self-help educational material (tools) included in the program was mainly based on the pedagogical framework of Brattberg ${ }^{25}$ and the pain dimensions in the Gate Control Theory of pain. ${ }^{26}$ The major contribution of this model is an emphasis on the central nervous system and psychological variables in the pain perception process. Each session began by giving a brief summary of the last group meeting, followed by sharing positive experiences over the past week. A review of the group members' home practice provided a platform for the supervised dialogue. This program, including follow-up after 6 and 12 months, consisted of three parts: supervised dialogue, physical activity and education. Each session lasted for 5 hours including a lunch break.

\section{Grief management program}

The various assignments or subjects in the writing program, make the different aspects of the grief process more tangible. The leaders of the grief writing group were deacons with experience of grief work groups. The participants were divided into two groups: one group consisted of individuals who had experienced the loss of a spouse or a partner. The other group consisted of individuals who had lost a parent or a sibling. Throughout the program the writing was done along two parallel tracks: writing in a grief writing group and writing at home in a diary. At each meeting of the writing groups, the writing was centered on a subject or an assignment. The types of writing that were encouraged as processing tools, were free writing forms and focused writing. Conversation before the writing commenced was encouraged in order to introduce and focus on the theme of the day. Conversation after writing in the group was also encouraged, giving each participant the opportunity to converse about thoughts and feelings related to the writing.

In each writing group meeting the participants were encouraged to write a diary at home. The writing in these diaries was based on personal wishes or initiatives. In addition, homework with writing based on specific topics was introduced. The writing program lasted for 5 months during which group meetings were held every 2 weeks during the initial 3 months, with one meeting in each of the following months, a total of 10 meetings.

\section{Methods}

Several methodological steps were followed in this comparative study using an open qualitative approach:

Step 1: A process of reflection and discussion focused on content, organization, similarities and differences related to 
grief and loss in our previous implemented pain and grief management programs (Table 1, Appendix A).

Step 2: We discussed and reflected on how the theoretical framework in the first two-part article could be extended by focusing on the movements between "the relearning and adaptation" process ${ }^{1}$ and the qualitative data related to loss and grief. ${ }^{3-5}$

Step 3: A thematic analysis was carried out on the transcribed qualitative data from our intervention studies, by searching for common as well as distinctive categories related to experiences of loss and grief caused by death and chronic pain.

Step 4: An analytic reflection and abstraction was performed searching for common sub-themes and main theme (Table 2).

Step 5: A search was made for a model to clarify the connections between the sub-themes related to loss, grief and chronic pain and a main theme (Figure 1).

Step 6: Based on the previous analytic steps, suggestions for a new integrated framework was discussed.

\section{Results}

The discussion revealed several common main components within each program such as systematic writing and

Table 2 Categories, sub-themes and themes from the thematic analysis of the transcripts from the grief and chronic pain management groups

\begin{tabular}{|c|c|c|c|}
\hline Life phenomena & Categories & Sub-theme & Theme \\
\hline $\begin{array}{l}\text { Loss of a close } \\
\text { one-grief }\end{array}$ & $\begin{array}{l}\text { aDifferent related } \\
\text { losses } \\
\text { aPainful } \\
\text { bereavement } \\
\text { Loneliness } \\
\text { aPainful and } \\
\text { depressive thoughts } \\
\text { and feelings } \\
{ }^{\text {aAnger }} \\
{ }^{\text {bDespair }} \\
\text { bMelancholy }\end{array}$ & $\begin{array}{l}\text { Emptiness } \\
\text { Vulnerability } \\
\text { Exhaustion }\end{array}$ & $\begin{array}{l}\text { Existential } \\
\text { vacuum }\end{array}$ \\
\hline $\begin{array}{l}\text { Chronic pain- } \\
\text { loss-grief }\end{array}$ & $\begin{array}{l}\text { a Different related } \\
\text { losses } \\
\text { aPainful } \\
\text { bereavement } \\
{ }^{\mathrm{a}} \text { Loneliness } \\
{ }^{\text {a Painful and }} \\
\text { depressive thoughts } \\
\text { and feelings } \\
{ }^{\mathrm{a}} \text { Anger } \\
{ }^{\mathrm{b}} \text { Resignation } \\
{ }^{\mathrm{b}} \text { Frustration }\end{array}$ & & \\
\hline
\end{tabular}

Notes: a Common identified experiences; ${ }^{\mathrm{b} D}$ ifferent identified experiences. homework combined with group dialogue, and a supervised dialogue where thoughts and feelings related to what was lost were conceptualized (Table 1). Both studies had empirical data which resulted from writing individually in groups and notes from homework tasks. Categorized experiences which were expressed in the grief groups were different related losses, painful bereavement, loneliness, painful and depressive thoughts and feelings, anger, despair and sadness. In the pain groups, the experiences were different related losses, painful bereavement, loneliness, painful and depressive thoughts and feelings, frustration, anger and resignation (Table 2). Common sub-themes for these categories were identified as: emptiness, vulnerability and exhaustion as important features. By linking the sub-themes together a common core emerges and is labeled existential vacuum identical to main theme (Figure 1). The results are illustrated as overlapping experiences (Figure 1).

\section{Discussion}

Based on the authors' previous studies ${ }^{1,3-5}$ and the findings from the thematic analysis in this study, we now want to extend the discussion in order to deepen our understanding of grief processes. Furthermore, we will highlight important elements when developing integrated programs in chronic pain- and grief management.

In both of our studies ${ }^{3-5}$ the participants experienced loss and grief and realized that some sort of help was needed. To offer help a phenomenological perspective on loss and grief caused by death and chronic pain, means that the whole life situation must be considered in program development. Grief

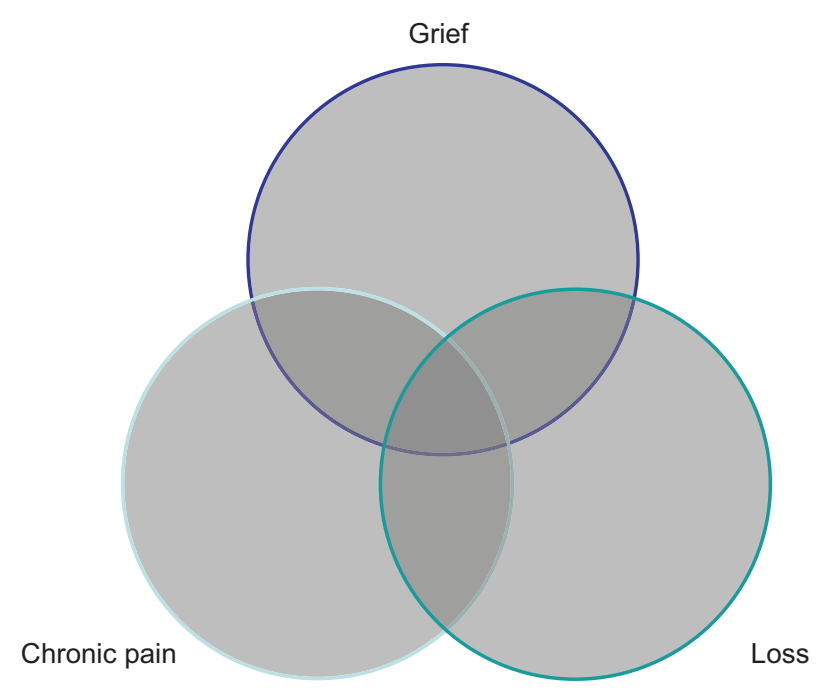

Figure I Results illustrating the overlapping experiences between chronic pain, loss and grief. The common core is characterized as an existential vacuum containing emptiness, vulnerability and exhaustion. 
is a normal human response to a significant loss. The death of a close relative is considered the ultimate loss. Such loss is obvious and the grief process is recognized by attention from others. However, with chronic pain the loss may be complete or partial. The grief which follows may be less obvious and may limit support from other people. ${ }^{2}$ The present results indicate a relationship between loss, grief and chronic nonmalignant pain. This is supported by both previous and more recent research which document a relationship between these phenomena and the development of illness. ${ }^{8,27}$ Parkes $^{8}$ has identified parallel processes of grieving independent of the type of loss.

Results from several studies on writing and the health effects indicate that positive health is achievable through writing about traumatic and demanding experiences. ${ }^{28,29}$ Furthermore, interventions based on a CBT approach offered to patients suffering from chronic pain, with active patient participation, indicate positive results. ${ }^{30}$ Writing therapy has emerged as a way to ease grief related to loss by death and chronic pain by tapping into the healing power of the unconscious. $^{31}$ Whitley-Reed $^{10}$ reports that grief therapy may be effective in reducing pain in a group of chronic pain sufferers. Grief supporting in groups are common and helpful because the patients represent common life experience and this gives opportunity to tell one's own story and ventilate feelings..$^{3-5,32}$ These benefits from group approaches are also described by Yalom ${ }^{12}$ who emphasizes the importance of interpersonal learning, self-disclosure and the expression of emotions. Taking together, these results support the importance of developing chronic pain- and grief management programs.

In accordance with our view, professional intervention must be aimed directly at each individual relation and the position in "the relearning and adaptation process." ${ }^{\text {"1 }}$ As such, grief cannot be reduced to observable and fragmented symptoms. ${ }^{1,5}$ Surprisingly, most of the identified experiences caused by loss and grief related to death of a close person and suffering from chronic pain were overlapping (categories in Table 2). These overlapping experiences are incorporated in the sub-themes emptiness, vulnerability and exhaustion. Based on this understanding, a clarifying model is suggested, which indicates that these life phenomena not only overlap, but also have an inner dynamic and a common core (Figure 1). These experiences also involve several cognitive, affective and bodily manifestations which might be met by using a cognitive behavioral approach. Despite some identified different experiences which are naturally connected to the specific losses, we argue that the common experiences are central when developing an integrated program in chronic pain- and grief management. In addition, the elements in the common core become basic areas to address in future clinical programs.

However, the first and foremost plan must involve the dialectic process between "relearning and adaptation" as described in our previous theoretical work. ${ }^{1}$ Here a model illustrates parallel processes characterized by conflicting experiences such as despair and hope, lack of understanding and insight, meaning disruption and increased meaning, bodily discomfort and reintegrated body. ${ }^{1}$ The present extended theoretical fundament including the complexity described above represent a challenge in clinical practice. Such knowledge presupposes that health care workers have adequate knowledge about each of the life experiences, as well as the common core and how they appear in each individual. If not, the burden for those experiencing losses and grief may increase and become even heavier.

Usually, as time passes by, the sufferer and her or his network will obtain an optimal functional level. However, some patients are unable to handle their losses effectively, and this may intensify the painful experience. ${ }^{6}$ The challenge is to find out who will need some sort of support from health care providers. In order to better understand the poorly adaptive as well as the adaptive processes, one must examine the unique movements. Throughout the grief process thoughts and feelings may vary in their nature and intensity. The core represents experiences which may be multifaceted and so overwhelming that the patient becomes unable to take action. Listening to the patients' expressions of grief can be therapeutic in itself. ${ }^{33}$ The unique experience becomes basic for intervention. Summing up, the rehabilitation process must pay attention to the unique experiences illustrated in the "relearning the world - adaptation model" and extended by the present "Common core model" (Figure 1), linking part one ${ }^{1}$ and part two of these two-part articles together.

\section{Implications for practice}

Grief work is recognized to be an important (although painful) process which also may create relief. It is essential to be aware that the grieving process varies in strength and endurance, ${ }^{5}$ so that the programs must consider individual variations in length and intensity in the follow-up. When preparing interventions, attention must also be paid to "the relearning and adaptation process", ${ }^{1}$ the interplay between chronic pain, loss and grief and the common core. This represents an integrated framework developed by linking part one and part two of these two-part articles together. An important aim in grief and pain management programs, is 
to create hope, insight, meaning, and a reintegrated body. ${ }^{1}$ We suggest that writing theory, from the grief management program may be integrated in the pain management program, based on a CBT approach and vice versa. Such combination might represent an improved intervention for people dealing with grief related to loss and nonmalignant chronic pain.

Based on this comparative study, a summary of points for developing and implementing such programs is suggested: an introduction of systematic writing and homework combined with a supervised dialogue, where thoughts and feelings related to what is lost is conceptualized and processed. In addition, practical elements such as focusing on supportive factors, interpersonal learning, self-revelation and self-understanding must be highlighted. ${ }^{12}$ Establishing a good relation between the health care provider, the sufferer and social support is described as the single most underlying important skill if interventions are to succeed. ${ }^{32}$ These suggestions might lead to more focus on the relation between chronic pain, loss and grief and better treatment.

\section{Conclusion}

Experiencing grief caused by death of someone close and chronic nonmalignant pain, is about whole bodies and the unique experiences. An extended approach has been developed for grief interventions based on the authors' previous work, the first two-part article and our present theoretical framework. We believe there is value in future research to consider loss and grief caused by death of someone close or by chronic pain more broadly, to develop our knowledge base. As such, understanding the processes involved in one of the loss and grief situations may help us understand the processes involved in the other. It may also turn out that treatment issues are similar in the different kinds of losses which are experienced. This study has led to new questions that might be further investigated in a pilot project for clinical practice using our outlined models and suggestions.

\section{Disclosure}

The authors report no conflicts of interest in this work.

\section{References}

1. Furnes B, Dysvik E. Dealing with grief related to loss by death and chronic pain. An integrated theoretical framework. Part 1. Patient Preference and Adherence. 2010;4:135-140.

2. Lindgren CL. Chronic sorrow in long-term illness across the life span. In: Fitzgerald Miller J. Coping with Chronic Illness, Overcoming Powerlessness. Philadelphia, PA: Davis; 2000:125-143.

3. Dysvik E. Health-related Quality of Life and Coping in Rehabilitation of People Suffering from Chronic Pain. Doctoral thesis. University of Bergen, Norway, 2006.
4. Dysvik E, Kvaløy JT, Stokkeland R, Natvig GK. The effectiveness of a multidisciplinary pain management programme managing chronic pain on pain perceptions, health-related quality of life and stages of change- A non-randomized controlled study. Int J Nurs Stud. 2010;47:826-835.

5. Furnes B. A Skrive Sorgen - Bearbeidelse av sorg. Prosessorientert skriving i møte med en fenomenologisk språkforståelse. En hermeneutisk fenomenologisk studie av skriving som sorgbearbeidelse hos etterlatte. Doctoral thesis. University of Bergen, Norway, 2008.

6. Gatchel RJ, Adams L, Polatin PB, Kishino ND. Secondary loss and pain-Associated disability: Theoretical overview and treatment implications. J Occ Rehab. 2002;12:99-109.

7. Miller ED, Omarzu J. New directions in loss research. In: Harvey JH, editor. Perspectives on loss, a sourcebook. Philadelphia: Taylor and Francis; 1998:3-20.

8. Parkes CM. Bereavement: Studies of Grief in Adult Life. London: Penguin; 1986

9. Walker J, Sofaer B, Holloway I. The experience of chronic back pain: Accounts of loss in those seeing help from pain clinics. Eur J Pain. 2006;10:199-207.

10. Whitley-Reed L. The efficacy of grief therapy as a treatment modality for individuals diagnosed with co-morbid disorders of chronic pain and depression. Dissertation Abstracts International: Section B-Sciences and Engineering. 1999;59(7B):3710.

11. Keefe FJ, Beaupre PM, Gil KM, Rumble ME, Aspnes AK. Group therapy for patients with chronic pain. In: Turk DC, Gatchel RJ, editors. Psychological Approaches to Pain Management. A practitioner's handbook. 2nd ed. New York, NY: Guilford Press; 2002: 234-255.

12. Yalom ID. The Theory and Practice of Group Psychotherapy. 5th ed. New York, NY: Basic Books; 2005.

13. Linton SJ. Understanding Pain for Better Clinical Practice: A psychological perspective. London, UK: Elsevier; 2005.

14. Turk DC, Monarch ES. Biopsychosocial perspective on chronic pain. In: Turk, DC, Gatchel RJ, editors. Psychological Approaches to Pain Management. A practitioner's handbook. 2nd ed. New York, NY: Guilford Press; 2002:3-29.

15. Turk DC. A cognitive-behavioral perspective on treatment of chronic pain patients. In: Turk DC, Gatchel RJ, editors. Psychological Approaches to Pain Management. A practitioner's handbook. 2nd ed. New York, NY: Guilford Press; 2002:138-158.

16. Vygotsky L. Teenkning og Sprog II. København: H:Reizel;1982.

17. Elbow P. Writing without Teachers. New York, NY: Oxford University Press; 1973.

18. Murray D. Indre revisjon - en oppdagelsesprosess. In: Bjørkvold E, Penne S, editors. Skriveteori. Oslo, Norway: LNU/ J.W Cappelens Forlag A/S; 1991.

19. Dysthe O, Hertzberg F, Hoel TL. Skrive for å laere. Skriving i høyere utdanning. Abstrakt forlag: Portalserien; 2000.

20. Elbow P. Writing with Power. Techniques for mastering the writing process. Oxford, UK: Oxford University Press; 1981.

21. Britton J, Burgess T, Martin N, McLeod A, Rosen H. The development of Writing-abilities. London, UK: Macmillan Education; 1975: 11-18.

22. Stensland P. Approaching the Locked Dialogues of the Body-Communicating symptoms through illness diaries. Doctoral thesis. Division for General Practice, Department of Public Health and Primary Health Care. University of Bergen, Norway, 2003

23. Pennebaker JW. Telling stories: The health benefits of narrative. Lit Med. 2000;19:3-11.

24. Smyth J, True N, Souto J. Effects of writing about traumatic experiences: The necessity for narrative structuring. J Soc Clin Psych. 2001; 20:161-172.

25. Brattberg G. Väckarklockor för Människor I Livets Väntrum. Stockholm, Sweden: Värkstaden; 1998.

26. Melzack R, Wall PD. Pain mechanisms: a new theory. Science. 1965;150:971-979. 
27. Stroebe MS, Hansson RO, Stroebe W, Schut H. Introduction: concepts and issues in contemporary research on bereavement. In: Stroebe MS, Hansson RO, Stroebe W, Schut H, editors. American Handbook of Bereavement Research. Consequences, coping, and care. Washington DC: Psychological Association; 2002:3-22.

28. Francis ME, Pennebaker JW. Putting stress into words: The impact of writing on physiological, absentee and self-reported emotional wellbeing measures. Am J Health Prom. 1992;6:280-207.

29. Smyth J. Written emotional expression: Effect sizes, outcome types, and moderating variables. J Consulting Clin Psych. 1998;66:174-184.
30. Turk DC, Burwinkle TA. Cognitive-behavioral perspective on chronic pain patients. Crit Rev Physil Rehab Med. 2006;18(1):1-38.

31. Rashbaum IG, Sarno JE. Psychosomatic concepts in chronic pain. Arch Phys Med Rehab. 2003;84:76-85.

32. Miller Kahn A. Coping with fear and grieving. In: Lubkin IM, editor. Chronic Illness, Impact and Interventions. London, UK: Jones and Bartlett; 1995:241-260.

33. Dyregrov K. The Loss of a Child by Suicide, SIDS, and accidents: Consequences, needs and provisions of help. Doctoral thesis. University of Bergen, Norway, 2003. 


\section{Appendix A}

Appendix A Content of the pain and grief management program

\begin{tabular}{|c|c|c|}
\hline Meeting & Pain management & Grief management \\
\hline I & Establishing the group. Develop goals & Writing about present life situation \\
\hline 2 & $\begin{array}{l}\text { Physical activity and pain. Develop } \\
\text { own plan for activity }\end{array}$ & A description of the person who is lost \\
\hline 3 & $\begin{array}{l}\text { Pain as a complex phenomenon. } \\
\text { Awareness of factors } \\
\text { increasing/decreasing pain }\end{array}$ & $\begin{array}{l}\text { A story about an important occasion together with } \\
\text { the person who is lost }\end{array}$ \\
\hline 4 & $\begin{array}{l}\text { Muscle tension, relaxation and pain. } \\
\text { Practice in relaxation techniques }\end{array}$ & Writing a letter/obituary for the lost person \\
\hline 5 & $\begin{array}{l}\text { Coping and pain. Awareness of coping } \\
\text { strategies and alternative ways of coping }\end{array}$ & Defining despair and guilt \\
\hline 6 & $\begin{array}{l}\text { Self-esteem, social network and pain. } \\
\text { Awareness of self-esteem and social } \\
\text { network and alternative ways of behaving }\end{array}$ & $\begin{array}{l}\text { Writing a story based on pictures which illustrate } \\
\text { different aspects of grief utterance } \\
\text { Home writing based on a previous theme }\end{array}$ \\
\hline 7 & $\begin{array}{l}\text { Thoughts, feelings and behavior and } \\
\text { how they relate to each other }\end{array}$ & $\begin{array}{l}\text { Defining loss and loneliness } \\
\text { Home writing about a good memory }\end{array}$ \\
\hline 8 & $\begin{array}{l}\text { Communication. Self-help. Awareness } \\
\text { of important factors in communication }\end{array}$ & $\begin{array}{l}\text { Relationship previous and present to important persons } \\
\text { Homework with writing about good and bad } \\
\text { thoughts and feelings during the last few days }\end{array}$ \\
\hline 9 & $\begin{array}{l}\text { Nutrition and pain. Awareness of how } \\
\text { nutrition can influence pain }\end{array}$ & $\begin{array}{l}\text { Experience of grief and longing/hope and joy } \\
\text { Home writing about situations related to a strong } \\
\text { feeling of grief/situations related to joy }\end{array}$ \\
\hline 10 & Repetition, main goals basic assumptions & $\begin{array}{l}\text { Writing about what is important to know; the capability } \\
\text { to meet the new life situation, a meaningful life and } \\
\text { future plans }\end{array}$ \\
\hline
\end{tabular}

Patient Preference and Adherence

Dovepress

\section{Publish your work in this journal}

Patient Preference and Adherence is an international, peer-reviewed, open access journal that focusing on the growing importance of patient preference and adherence throughout the therapeutic continuum. Patient satisfaction, acceptability, quality of life, compliance, persistence and their role in developing new therapeutic modalities and compounds to optimize clinical outcomes for existing disease states are major areas of interest. This journal has been accepted for indexing on PubMed Central. The manuscript management system is completely online and includes a very quick and fair peer-review system. Visit http://www.dovepress.com/ testimonials.php to read real quotes from published authors. 